\title{
Approaching Social Setting when Analyzing Language Change in the Early Republic
}

\author{
By Virginia A. G. Meirelles*
}

\begin{abstract}
Any study that concentrates on language change should assess factors such as historical context and social structure. ${ }^{1}$ However, approaching the phonetic and phonological changes that took place during the Early American Republic (1776-1861) is a complex task since it was a period of considerable social, political and economic reorganization ${ }^{2}$ Additionally, although many biographies and studies on selected issues have been written, the scholarship about the period remains unconnected and fragmented. ${ }^{3}$ As such, this article exposes the theoretical and methodological preparation for a research on sound change during the Early American Republic by discussing how to undertake data collection and how to approach data analysis.
\end{abstract}

\section{Introduction}

The Early Republic (ER) was characterized by many events like the development of political parties, the hostility between those parties, foreign relations issues, and the westward movement. In the half century after the Revolution, "political institutions were established" (Congress, Supreme Court) and "a political economy was worked out." ${ }^{4}$ The territorial expansion and industrialization raised considerable controversy over topics such as slavery and Native Americans. It is true that the expansion opened the country to settlers who were looking for a better life but, at the same time, it displaced the Native Americans and triggered the debate over whether slavery should be allowed in the new territories or states. Additionally, the Industrial Revolution transformed North America into an industrialized nation with a capitalistic economy that in turn affected the social structure and generated disagreements connected to the perpetuation of slavery. Indeed, because of the dramatic socio-economic changes

"Professor, University of Brasília, Brazil.

1. P. Trudgill and R. Watts, Alternative Histories of English (London/NY: Routledge, 2002); M. Laing, "Multidimensionality: Time, Space and Stratigraphy in Historical Dialectology," in M. Dossena and R. Lass (eds.), Methods and Data in English Historical Dialectology (Germany: Peter Lang, 2004), 49-96.

2. C. Clark, "Comment on the Symposium on Class in the Early Republic," Journal of the Early Republic 25, no. 3 (2005): 559.

3. E. Pessen, "Social Structure and Politics in American History," The American Historical Review 87, no. 5 (1982): 1290-1325; G. S. Wood, "The Significance of the Early Republic." Journal of the Early Republic 8, no. 1 (1988): 1-20.

4. Ibid, 1. 
and technological advances, the United States (U.S.) emerged as a very different nation from the colony that had declared independence. ${ }^{5}$

In terms of the linguistic situation, while some records indicate that during the early 1800s, the Englishmen did not tell American and British varieties apart, ${ }^{6}$ others reveal that the English were aware of the peculiarities of the American variety. ${ }^{7}$ Likewise, some reports mention that in the 18th and early 19th centuries, the English in America was uniform ${ }^{8}$ but others show that by 1780 residents in the South and North were conscious of speech differences. ${ }^{9}$ The disparity of the reports may be explained because settlers brought American English from different parts of the British Isles at different times. As a consequence, it is possible that different combinations of dialects were present in different proportions in different areas and were evaluated differently by Englishmen. However, that dialect mixture situation did not last more than a generation or two when people living in the same location leveled out the original dialects, giving rise to koinézation. ${ }^{10}$ As a result, in the early years of settlement, dialect differences were established on the east coast as each community adopted a dialect that was 'mixed' with respect to its origins, but uniform in its current characteristics throughout the community. ${ }^{11}$

At the same time, since national identification and language awareness are interconnected ${ }^{12}$ and since American nationalism emerged after the Revolution, ${ }^{13}$

5. J. T. Lemon and G.B. Nash, "The Distribution of Wealth in Eighteenth-Century America: A Century of Change in Chester County, Pennsylvania, 1693-1802," Journal of Social History 2, no. 1 (1968): 1-24; E. Pessen, "Social Structure and Politics in American History," 1982; G. S. Wood, "The Significance of the Early Republic," 1988; M. Zakim, "The Business Clerk as Social Revolutionary; or, a Labor History of the Non-Producing Classes," Journal of the Early Republic 26, no. 4 (2006): 563-603.

6. J. Fisher, "British and American, Continuity and Divergence," in J. Algeo (ed.), The Cambridge History of the English Language (Cambridge University Press, 2001), 73.

7. J. L. Dillard, Perspectives on American English (The Hague: Mouton, 1980), 3; A. W. Read, "British Recognition of American Speech in the Eighteenth Century," in J. L. Dillard (ed.), Perspectives on American English (The Hague: Mouton, 1980), 15-35.

8. T. Twining, Travels in America 100 Years Ago: Being Notes and Reminiscences (New York: Harper and Brothers, Publishers, 1894); J. L. Dillard, Perspectives on American English, 1980, 20-22.

9. M. Montgomery, "The Crucial Century for English in the American South," in M. D. Picone, C. E. Davies (eds.), New Perspectives on Language Variety in the South: Historical and Contemporary Approaches (Tuscaloosa, Alabama: The University of Alabama Press, 2015).

10. P. Trudgill, Sociolinguistics: An Introduction to Language and Society (London: Penguin, 2000), 157.

11. Ibid.

12. E. Haugen, "Dialect, Language, Nation," American Anthropologist 68: (1966): 922935.

13. G. S. Wood, “The Significance of the Early Republic,” 1988, 1. 
it is expected that the formative period of the American variety might have started after the Revolutionary War. In fact, according to Montgomery, ${ }^{14}$ the emergence of a Standard American English goes back to one or two generations before the Civil War (1861-1865) with the formation of regional and social variations simultaneously, ${ }^{15}$ a situation that must have been influenced by the intense internal migration that was taking place at the period.

Because both linguistic and social factors affect language change, studies of the diffusion of language change need to consider social aspects. To examine how social and economic events may have influenced the diffusion of changes, this article describes the relevant historical events of the ER by summarizing, in sequence, the economic, demographic and cultural changes that took place during the period. Special attention is given to the changes in class structure because social barriers may halt the diffusion of linguistic features. Demographic and migratory details are included because they may provide valuable information to access linguistic diffusion, at the time that reports on the level of literacy of men and women may help decide on the kind of documents that should be examined. As such, the objective of this article is to consider the relevant historical events and the socio-economic conditions of the ER and propose an approach to the examination of written documents that will create a corpus that is representative of the period. The article examines, first, the historical events, the demographic conditions, the social structure, the economic changes and the level of literacy at the time. After that, it discusses the influence those aspects may have had on the diffusion of language change. Lastly, it proposes a methodology for collecting data for a research study that analyses language change in the ER.

\section{Literature Review}

\section{Historical Events}

The Second Continental Congress issued the Declaration of Independence in 1776 and in 1789, the Articles of Confederation (adopted in 1777) were replaced by the Constitution of the United States of America which created a new independent nation. The same year, George Washington was elected first president.

During the first years after the Declaration of Independence, there were no political parties. However, factions started to form around dominant personalities which later gave birth to two parties. The Federalist Party (Alexander Hamilton) had the support of merchants and financiers throughout the country, favored

14. M. Montgomery, “The Crucial Century for English in the American South,” 2015, 99.

15. M. Montgomery, "The History of American English," in D. R. Preston (ed.), Needed Research in American Dialects (N.C.: Duke University Press, 2004), 1. 
Britain in its battles with France and vehemently defended a strong Federal constitution. The Federalists dominated until 1800 when Jefferson's victory diminished their influence. On the other hand, the Republicans (Thomas Jefferson and James Madison) identified mostly with farmers who opposed the new federal taxes created by the Federalists and feared the loss of individual and state rights by a concentration of central authority with the creation of a strong federal government.

In fact, in its first years, the new country witnessed insurrections and debates over nationalism, individualism and state control. During the 1780s, due to the government mismanagement of economic issues, rebellions erupted, principally, in Massachusetts and Pennsylvania. Additionally, the fear of losing individual rights and the opposition of the antifederalist to the creation of a stronger federal government resulted in negotiations over the ratification of the Constitution that lasted several years. Because of that, not all the thirteen states ratified the Constitution at the same time.

American politics became more democratic in the 1820s when the requirements for voters to own property were abolished and the printed ballots were adopted. The period between 1828 and 1854 was characterized by rising levels of voter interest and high degrees of personal loyalty to parties. Two parties dominated the scene: Whigs (John Quincy Adams, Daniel Webster) who represented the wealthier planters, merchants, financiers, and professionals and wanted to modernize the society by creating a transportation infrastructure; and Jacksonians (Andrew Jackson, Stephen Douglas) who advanced expansion of farmers and planters into new lands.

At that time, the U.S. depended on maritime transport of agricultural goods. However, because of the war with Napoleon, Britain had taken a series of actions, among which was establishing a naval blockade, to impede trade between France and the U.S., and creating an allegiance with Native Americans to obstruct American expansionism and trade with Canada. The blockade intensified the growing tensions between Britain and the U.S. and finally resulted in a declaration of war in 1812. The war (1812-1815) affected the transportation of goods and, consequently, destroyed the American Economy. After the war, nationalism increased across the country, at the same time that a sense of sectionalism and individualism grew.

The Native Americans were unable to stop white settlement after the War of 1812 because they lost British support. As a consequence, in 1830, Congress passed the Indian Removal Act and in 1834, a special Indian Territory (now part of Oklahoma) was established. The Native Americans were promptly forced to move to that territory in what came to be known as the "Trail of Tears".

The territorial expansion started in 1803 with the Louisiana Purchase and continued throughout the period. In 1818, Britain agreed to settle the western border with Canada (the eastern border was settled in 1845) and in 1819, the Spanish agreed to cede Florida Territory to the U.S. Soon after, settlers began 
moving into Texas (1820) and into the Pacific Northwest (1830). Texas was annexed in 1845; Oregon became a state in 1846; and, Arizona was purchased in 1854. As a result of the territorial expansion, by 1864, the original thirteen colonies had become 36 states. Yet, since the North (anti-slave) was against the annexation of Texas and the South (pro-slave) favored it, Texas annexation was viewed as a pro-slavery initiative which eventually contributed to the Civil War.

Overall, during the ER nationalism and individualism increased, at the same time that external and internal conflicts were common. The internal disputes were marked by oppositions that were in part related to geographic location federalists/antifederalists, small farmers/wealthier planters, North/South, expansionists/anti-expansionists. In linguistic terms, the growing nationalism may have stimulated the adoption of American variants. In addition, the antagonism within the country may have prevented the spreading of changes by creating invisible barriers to the existent natural ones. For those reasons, the differences between North and South and the consequences of the territorial expansion will be examined in the next section.

\section{Demography}

The population of the U.S. that in 1700 was 250,000 inhabitants, in 1790 had reached 4 million people, and in 1861, 30 million. Yet, it was as heterogeneous as it had been since the beginning. In fact, it was only in the New England states that travelers say to have met unmixed descendants of Englishmen. ${ }^{16}$

The original thirteen colonies were grouped into three regions: the New England (or Eastern) states, the Middle states and the Southern states. The New England states (NE) were mostly settled by Pilgrims (lower class) and Puritans (middle class) who composed about 75\% of the American population in 1776. Harriott mentions that in this region the inhabitants had good manners and a love of letters.

On the other hand, the Middle states had a mixed, but predominantly European origin, ${ }^{17}$ although some Natives were also reported in urban areas. ${ }^{18}$ The population consisted mostly of manual workers or shopkeepers ${ }^{19}$ and, contrary to

16. J. Harriott, Struggles through Life (Dublin: John Exshaw, 1815), 38; J. H. St. John de Crèvecoeur, Letters from an American Farmer (London: For the Author, 1782).

17. J. Algeo, The Cambridge History of the English Language (UK: Cambridge University Press, 2001), 11.

18. J. Harriott, Struggles through Life, 1815, 39-42; J. H. St. John de Crèvecoeur, Letters from an American Farmer, 1782, 177-193; D. Ford, Journal of an Expedition Made in the Autumn of 1794 (The New York Public Library, 1794).

19. J. T. Main, The Social Structure of Revolutionary America (Princeton: Princeton University Press, 1965). 
Harriott's description of the NE inhabitants, the population in Pennsylvania (at least) was described as ignorant. ${ }^{20}$

Travelers describe the Southern states as being very similar to each other and having a social structure that was more rigid than that of the north with two distinct classes: lower and upper. ${ }^{21}$ However, similarly to the Middle States, the population was mixed. There were the Scotch-Irish who had come from Scotland, the North of England and Northern Ireland and were mostly indentured servants who initially moved to Maryland, Virginia, and North Carolina and then to the Appalachian region. ${ }^{22}$ There were French families in Baltimore who had arrived from the West Indies. ${ }^{23}$ There were also many slaves (40\% of the population of Maryland by the end of the 18th century). According to travelers, the black people in the South spoke good English; ${ }^{24}$ but were less skillful than Native Americans as sawyers, carpenters, smiths, and coopers ${ }^{25}$ while the Native Americans living in the south are described as less aggressive than the ones in the north but reported to hate black people. ${ }^{26}$

The poor in the South were characterized as ignorant, addicted to drinking, to horseracing and to swearing by St. John de Crèvecoeur. ${ }^{27}$ On the other hand, the upper classes in Virginia and North Carolina reportedly maintained a closer connection with Britain than the other states did. In fact, Jones ${ }^{28}$ describes Virginia as "the most valuable gem in the Crown of Great Britain" and mentions that the Virginians were identical in costumes to Londoners: they sent their sons to be instructed in England and read fine works. Moreover, they did not understand sailors, dealers and servants that come from towns in rural areas of England and Scotland.

In any case, expansionism started in 1803 with the Louisiana Purchase and saw its revival in the 1840s with the annexation of Texas and the Gold Rush. On the other hand, external migration was shortly interrupted during the first years of the ER but restarted in the 1830s when people seeking for freedom and better life conditions arrived in the U.S. coming mostly from Britain, Ireland, Germany,

20. D. Ford, Journal of an Expedition Made in the Autumn of 1794, 1794.

21. W. Bartram, Travels through North $\mathcal{E}$ South Carolina, Georgia, East $\mathcal{E}$ West Florida, the Cherokee Country, the Extensive Territories of the Muscgulges, or Creek Confederacy, and the Country of the Chactaws (Philadelphia: Printed by James \& Johnson, 1791); H. Jones, The Present State of Virginia (London: J. Clarke, 1865).

22. J. Algeo, The Cambridge History of the English Language, 2001, 13.

23. J. H. St. John de Crèvecoeur, Letters from an American Farmer, 1782, 301.

24. H. Jones, The Present State of Virginia, 1865; J. H. St. John de Crèvecoeur, Letters from an American Farmer, 1782.

25. H. Jones, The Present State of Virginia, 1865.

26. Ibid, 4-17.

27. J. H. St. John de Crèvecoeur, Letters from an American Farmer, 1782, 215.

28. H. Jones, The Present State of Virginia, 1865. 
France, and Scandinavia (599,000 immigrants from 1831 to 1840 and 1,713,000 from 1841 to 1850$)$.

Indeed, in the second half of the 18th century, Europeans entered through NE and New York and eventually moved to Ohio. Later, people from NE (Yankees) moved into Michigan and Chicago while Pennsylvanians migrated to Carolina, Georgia piedmont and to the southern mountains. In its first years, the population in Texas was composed of people coming from every part of the United States, mostly southerners to the lowlands and northerners to the interior. At the time, St. John's Parish (Louisiana) consisted chiefly of families who came from South Carolina ${ }^{29}$ whereas cities like Mobile (Alabama), Pensacola (Florida) and St. Louis (Mississippi) were inhabited by French families and emigrants from the Northern states. Additionally, the population in New Orleans was "made up of all nations, tongues and languages" and, even though there was internal migration in the early $19^{\text {th }}$ century to places like Ohio, Wisconsin and Michigan, emigrants from Europe were numerous. ${ }^{30}$ Germans, for example, who had entered through Baltimore, New York, Philadelphia, and New Orleans, made up one fourth of the inhabitants of Cincinnati in $1850 .{ }^{31}$

Considering the reasons, mechanisms and consequences of the expansion is relevant to the study, given that migration and territorial expansion can play an important role in the diffusion of changes from one place to another. ${ }^{32}$ Territorial expansion was stimulated by nationalism, religion and the idea of equality among citizens. More territory meant more power for the new nation, at the same time that access to the western land was a way of providing equal opportunities for all to reach individual prosperity. Additionally, many believed that the stretching of boundaries was a divine obligation so the territorial growth was considered blessed by God. As such, the territorial expansion could be seen as a necessity that justified the displacement of Native Americans. In addition, proslavery southerners, moved south because they needed more land to plant.

Although it is a fact that speakers acquire the linguistic characteristics of those they live in contact with, the spread of language features does not depend only on proximity. ${ }^{33}$ There is dominance of town over country, which means that innovations usually spread first from one urban area to another and only later to the countryside. ${ }^{34}$ For those reasons, it is important to emphasize that before 1850, the United States was essentially rural and the few existent cities were small. In 1810, there was no urban center larger than 100,000 and, in 1830, New York was

29. W. Bartram, Travels through North \& South Carolina, Georgia, East \& West Florida, 1791, 842-1053.

30. A. A. Parker, Trip to the West and Texas (USA: Concord, 1835), 165-222.

31. J. J. Mersman, The Whiskey Merchant's Diary (ed.) L Fisher (Ohio: Ohio University Press, 2007).

32. P. Trudgill, Sociolinguistics: An Introduction to Language and Society, 2000, 156.

33. Ibid, 43-150.

34. Ibid, 147-149. 
the only city with 100,000 inhabitants. In 1830, Cincinnati was the largest city in the West with less than 25,000 people. The presence of Native Americans was common (and even numerous) in many urban places in Illinois, Louisiana, Mississippi, Ohio, Tennessee and the Florida Territory. ${ }^{35}$ In fact, the influx of migrants helped maintain the extensive contact with other languages, which had been characteristic since colonial times (Native American Languages, African languages, and European languages).

\section{Social Structure and Economic Changes}

This section will present the objective criteria (property and income) that defined economic classes during the period, but at the same time, it will examine the opinions that helped characterize the social classes. ${ }^{36}$ In terms of prestige, farmers were the most prestigious group, followed by the clergy, lawyers, and doctors who ranked the same. Merchants had an intermediate status because, although they were wealthy, they were considered the most dangerous part of the community and were accused of profiteering. The artisans came below the merchants and free laborers, white servants, and slaves occupied the last position. ${ }^{37}$

Although the small farmer was the ideal American, the difference between poor and yeoman was probably imperceptible and depended basically on the fact that the farmers owned their land. In fact, before the 1850s there were few agricultural wageworkers because most farmers "did not have the means to hire them." ${ }^{38}$ Furthermore, in most parts of the country there was no clear distinction between subsistence and commercial farming. ${ }^{39}$ In addition, specialization was rare, for which reason, the local artisans and merchants practiced their trades as sidelines to farming. ${ }^{40}$ On the other hand, merchants and professional men in general were elected more frequently for Congress than farmers and they did not usually join the army while artisans and farmers did. Moreover, there was a difference between the North and the South in terms of access to military ranks.

35. H. Jones, The Present State of Virginia, 1865; W. Bartram, Travels through North \& South Carolina, Georgia, East \& West Florida, 1791; A. A. Parker, Trip to the West and Texas, 1835.

36. J. T. Main, The Social Structure of Revolutionary America, 1965, 197.

37. Ibid, 197-220.

38. J. M. Faragher, "History from the Inside-Out: Writing the History of Women in Rural America," American Quarterly 33, no. 5 (1981): 546.

39. J. T. Lemon and G.B. Nash, "The Distribution of Wealth in Eighteenth-Century America," 1968, 17.

40. J. M. Faragher, "History from the Inside-Out: Writing the History of Women in Rural America," 1981, 546. 
In the South, the higher-ranking officers were large landholders while in the North opportunities were equal. ${ }^{41}$

The ER began with a colonial society that was vertically organized and tied together by kinship and patron-client relations ${ }^{42}$ that was transformed during the Industrial Revolution into a country where land no longer guaranteed a relevant position because personal wealth became more important. An agrarian majority opposing an aristocratic minority characterized the first years of the Republic but Jefferson's election in 1800 marked the victory of the rural faction and opened the way to "the appearance of the common man." 43 The social structure of the period after the Revolution was more unequal between 1820 and 1830 than in the beginnings of the 19 th century, ${ }^{44}$ the gap between rich and poor was greater in cities than in rural areas ${ }^{45}$ and there were many differences between the North and the South. New England, for example, did not have a wealthy class, but a subsistence farm society composed of small independent landowners (yeomen) which "gave the impression that everyone in the North belonged to the middle class." ${ }^{46}$ On the other hand, the South had a numerous upper class and only $30 \%$ of freeholders. ${ }^{47}$

Between the Revolutionary and the Civil War, a new commercial nation was born stimulated by the technologies of the Industrial Revolution. At that time, the U.S. underwent an explosive transformation in infrastructure and communication. The postal service (1775), the expansion of the printing industry (1820-1830) and the telegraph (1843) fostered the expansion of education and social reform. Steam boat services (1807) and long-distance railroads (1827) promoted the rise of American industry by powering industries and creating national transportation networks. The opening of the Erie Canal (1825) created a navigable water route from New York City and the Atlantic Ocean to the Great Lakes and greatly enhanced development and economy. Those transformations modernized the nation and enabled an expansion in business stimulated by the movement of goods, money, and people across the nation. The number of business corporations multiplied because buying and selling to locals made people realize that prosperity could come from local trade. ${ }^{48}$ As such, the changes in the social structure during the ER were stimulated by the spread of commerce and resulted in an "egalitarian, individualistic, and money-making society." 49

41. J. T. Main, The Social Structure of Revolutionary America, 1965, 212-218.

42. Ibid; G. S. Wood, "The Significance of the Early Republic," 1988, 11.

43. G. S. Wood, "The Significance of the Early Republic," 1988, 6.

44. E. Pessen, "Social Structure and Politics in American History," 1982.

45. Ibid, 1303; J. T. Lemon and G.B. Nash, "The Distribution of Wealth in EighteenthCentury America," 1968, 23.

46. G. S. Wood, "The Significance of the Early Republic," 1988.

47. J. T. Main, The Social Structure of Revolutionary America, 1965, 7, 18.

48. G. S. Wood, "The Significance of the Early Republic," 1988, 13-14.

49. Ibid, 18. 
Main's analysis of the society in revolutionary America in terms of land ownership, income, culture and extent of social mobility results in a detailed depiction of the social structure at the time. According to his description, there was a Lower class that comprised slaves, white servants, sailors, and the industrious poor or ordinary free laborers (weavers, carpenters, coopers, tailors who possessed no land or very small estates). Indentured servants and slaves were the property of their masters. The Industrial Revolution, which modernized the country and benefited the middle class and the elites, did not bring advantages to the laborer. As a result, the working-class children did not normally attend school because they needed to work in factories and married women usually took piecework at home.

The Middle class (or middling status) was the largest and most important group in Revolutionary America and comprised several occupations and professions - small farmers, clergy, artisans, teachers, doctors, lawyers, ministers, etc. In terms of social evaluation, the clergy was respected but had small incomes. Lawyers and doctors had varied incomes and status, but were mostly disliked by the public. Justices and judges were respected by the community, but were disliked by lawyers and had a smaller income than them. The prosperous artisans (cooper, blacksmith, weaver, carpenter), at first, occupied an intermediate position in the prestige hierarchy (below the farmers) but, following the depression of the 1780's, they came to be regarded as essential occupations. Later on, with the Industrial Revolution, artisans and small merchants who owned small factories and stores became the emerging middle class that believed that hard work and education could help them have a better life. Therefore, middle class children and married women did not work. Children attended school so they could acquire the abilities to succeed in life and married women cared for the organization of their homes and the general education and well-being of their children. Additionally, the families began to limit the number of children.

The Upper class consisted of officers (who could have 3 times as much wealth as the civilians), distillers, goldsmiths, large farms owners and merchants. The mercantile class, despite being wealthy, was considered the most dangerous part of the community and did not have easy access to the polite society of the day. However, after the expansion of business in the North, colonial merchants who had traded tea, sugar and other commodities passed their wealth to their children who formed an industrial capitalist elite that distanced themselves from the newly wealthy manufacturing leaders and the growing middle class by promoting marriage between leading families, creating exclusive neighborhoods and social clubs. At the same time, by creating organizations and chambers of commerce they strengthened their bonds and protected their interests. The innovative occupation of business clerk had an important role in the social 
redefinition of economy and was well regarded in society because the aristocracy looked down on manual labor. ${ }^{50}$

\section{Culture and Literacy}

Since language change during the ER may only be approached by examining written documents, another important issue is that of literacy. The ability to read and write during that period is usually measured by the ability to affix a signature in documents - which shows the citizens were minimally literate. Based on town records investigations, Kaestle ${ }^{51}$ and Grubb ${ }^{52}$ conclude that between the 18th and mid-19th century the U.S. was a literate society by European standards. Noticeably, literacy rates were higher for men in the North - about $91 \%$ in the NE and $80 \%$ in the South - and in urban areas..$^{53}$ Additionally, the rate of what is considered full literacy was higher among the upper and middle classes. ${ }^{54}$ However, studies provide incongruent results for female literacy at the time between $45 \%$ and $90 \% .{ }^{55}$ Since formal schooling was not always available, the high level of literacy has been connected to the number of literate immigrants that arrived $^{56}$ and to community or household practices of teaching each other how to read $^{57}$.

Notwithstanding, signature literacy gathered from town records does not provide an exact account of the situation at the time. Wills, deeds, and petitions give only a partial description since those documents are representative of middle-aged or older males of the middle and upper classes, which means that

50. M. Zakim, M. “The Business Clerk as Social Revolutionary; or, a Labor History of the Non-Producing Classes," 2006, 569.

51. C. F. Kaestle, "The History of Literacy and the History of Readers," Review of Research in Education 12 (1985): 11-53.

52. F. W. Grubb, "Growth of Literacy in Colonial America: Longitudinal Patterns, Economic Models, and the Direction of Future Research," Social Science History 14, no. 4 (1990): 451-482.

53. Ibid, 453-475; C. F. Kaestle, "The History of Literacy and the History of Readers," 1985.

54. S. Wilentz, "On Class and Politics in Jacksonian America," Reviews in American History 10, no. 4 (1982): 45-63; C. F. Kaestle, "The History of Literacy and the History of Readers," 1985.

55. R. W. Herndon, "Research Note: Literacy among New England's Transient Poor, 1750-1800," Journal of Social History 29, no. 4 (1996): 963; C. F. Kaestle, "The History of Literacy and the History of Readers," 1985

56. F. W. Grubb, "Growth of Literacy in Colonial America: Longitudinal Patterns, Economic Models, and the Direction of Future Research," 1990, 459-461.

57. C. F. Kaestle, "The History of Literacy and the History of Readers," 1985; R. E. Gallman, "Changes in the Level of Literacy in a New Community of Early America," The Journal of Economic History 48, no. 3 (1988): 567-582. 
evidence for women and lower classes would be scarce..$^{58}$ In fact, white female illiteracy was commonplace until at least the second half of the nineteenth century. ${ }^{59}$

To get a better idea of literacy rate among women, 520 examinations of transients in fourteen Rhode Island towns were analyzed by Herndon. The study showed that females headed $56 \%$ households and that the literacy rate was half of the most conservative estimates between 1750 and $1800 .{ }^{60}$ At the same time, studies of signature literacy in other kinds of documents showed that between 1800 and $1840,30 \%$ merchant seamen could not sign and that $42 \%$ of the Army enlistees could not sign in 1800, 35\% in 1840 and $25 \%$ in $1850 .{ }^{61}$

Additionally, during the ER, concern with all manifestations of human intellectual achievement increased. ${ }^{62}$ Some of the outcomes were an architectural revolution and the production in the U.S. of pedagogical material like dictionaries and grammars (A Grammatical Institute of the English Language by Noah Webster; The Columbian Dictionary of the English Language by Caleb Alexander; An American Dictionary of the English Language by Noah Webster).

\section{Discussion}

Socio-economic aspects like age, gender, social class, literacy level influence language diffusion and language change. Accordingly, if the formation of regional and social varieties happened during the first half of the 19th century ${ }^{63}$ the intense social, cultural and economic transformations of the ER should have affected the formation of those varieties and their diffusion. At the same time, it is only possible to investigate the diffusion of sound changes in the past through the examination of written documents. Under those circumstances, it is essential that the selected documents are representative of the everyday speech of members of the community ${ }^{64}$ and consist of misspelled words or any feature that evidences a change in pronunciation. Because semiliterate people have a tendency to write

58. F. W. Grubb, "Growth of Literacy in Colonial America: Longitudinal Patterns, Economic Models, and the Direction of Future Research," 1990, 475; R. W. Herndon, "Research Note: Literacy among New England's Transient Poor, 1750-1800," 1996, 963.

59. J. M. Faragher, "History from the Inside-Out: Writing the History of Women in Rural America," 1981, 537.

60. R. W. Herndon, "Research Note: Literacy among New England's Transient Poor, 1750-1800," 1996.

61. C. F. Kaestle, "The History of Literacy and the History of Readers," 1985, 30.

62. G. S. Wood, "The Significance of the Early Republic," 1988, 16-17.

63. M. Montgomery, "The History of American English," 2004.

64. E. Schneider, E. "Investigating Historical Variation and Change in Written Documents," in J. K. Chambers, P. Trudgill and N. Schilling-Estes (eds.), The Handbook of Language Variation and Change (Oxford/Malden, MA: Blackwell, 2002), 67. 
phonetically, the misspellings and words that are spelled in different ways in documents they write are strong evidence to the pronunciation of the time. As such, the primary sources need to conform to some requirements. First, the written material should parallel speech as much as possible, so less standardized material would be more appropriate. Second, the material needs to be representative of all members of the community. In view of that, accessing a multi-genre corpus would contribute with a better perspective; however, different sources have characteristic strengths and weaknesses.

When considering the extent of standardization, as edited collections have gone through manipulation, they would not be useful. Also, historical documents (ex. town records) are standardized and normally represent only part of the population (upper ranks, literate people, men) for which reason they may not contribute much with the investigation. Ledgers may be more standardized if they belong to important companies, or less standardized if they record the trade of retailers or individual artisans. Elocution manuals, dictionaries, grammars and textbooks - especially spelling books - will be valuable as secondary sources because by the 1820s they became resources for teaching spelling not for teaching reading ${ }^{65}$ and provided comments regarding 'correct' pronunciation. Diaries, recipe books and autographed personal letters focus on the content, not on the form, which allows them to be written in a less standardized, sometimes informal, or even careless, style. Literary texts are not standardized but the data they provide may not be trustworthy because poetical compositions and rhyme may be influenced by fashion and rhyming styles. Furthermore, literary conversations may not be a completely reliable source. For example, a 19th century observer expressed that "no American ever spoke like the Yankee on the boards of minor theatres in London" 66 .

Concerning the representation of speech in written form, five categories have been identified. ${ }^{67}$ The first category records speech events exactly, directly and simultaneously (ex. trial records). The second category also records, but from notes or memory (ex. slaves narratives). The third category consists of potential utterances that the speaker/writer records (ex. diaries, letters). The fourth category is similar to the first one, but includes an evaluation of the utterance (ex. prescriptive texts). Finally, the fifth one is the recording of invented speech, as in literary works. Thus, for this study preference will be given to diaries and autographed letters as primary sources because they are not standardized and they resemble speech to a certain extent.

65. R. Altenbaugh, Historical Dictionary of American Education (Connecticut/ London: Greenwood Publishing Group, 1999).

66. M. Schele De Vere, Americanisms: the English of the New World (New York: C. Scribner \& company, 1872), 148-149.

67. E. Schneider, "Investigating Historical Variation and Change in Written Documents," 2002, 72-73. 
However, although there is little correspondence between speech and recipe books, they might also be interesting since they permit the comparison between authors. School notebooks would also be useful because they depict the spelling of learners belonging to all social classes. Ledgers and town records have similar vocabulary which would offer orthographic evidence for pronunciation and may permit comparison between them. Additionally, since town records belong to a highly standardized category the misspellings they might contain would be very revealing.

Whatever the kind of material, there is the need to find out as much as possible about who created them (year of birth, gender, social status, level of education and family circumstances) since biographical data is relevant to ensure that the author is assigned to the correct social group and consequently, that all social groups are represented. For that reason, the primary sources to investigate language change during the ER would include only documents whose author is known and ideally who is semi-literate because those informants would provide instances that are nearer to speech in terms of pronunciation. The literacy level is also relevant because, during the period, literacy was correlated, first with schooling, second with family wealth and third with the population density of the community $^{68}$. However, given that semi-literate citizens belong mostly to the lower classes, having more semi-literate informants will result in an unbalanced data among social ranks.

Another problem that arises is that the proportion of male informants will be bigger than that of women informants. First, because, as it has already been discussed, literacy was less common among women than among men. Additionally, handwritten records and autographed letters written by women in those centuries are fewer than those written by men. ${ }^{69}$ When those exist, they over represent upper and middle class urban women ${ }^{70}$ mainly because, despite the fact that rural women constituted the majority of the female population and had an important role as oral communicators, they were mostly illiterate or lacked the time to write letters and diaries. ${ }^{71}$

Apart from selecting the texts for the investigation, it is necessary to develop a system for classifying the speakers. Traditionally, the system of social classification concerns the access to sources of wealth or power ${ }^{72}$ but in the 18 th and $19^{\text {th }}$ it was

68. C. F. Kaestle, “The History of Literacy and the History of Readers," 1985, 31.

69. J. M. Faragher, "History from the Inside-Out: Writing the History of Women in Rural America," 1981; J. Purvis, “Using Primary Sources When Researching," Women's History from a Feminist Perspective, Women's History Review 1, no. 2 (1992): 273-306.

70. Ibid, 293.

71. J. M. Faragher, "History from the Inside-Out: Writing the History of Women in Rural America," 1981, 537-554.

72. C. Clark, "Comment on the Symposium on Class in the Early Republic," 2005, 557564. 
determined by century kinship, occupation, politics and property. ${ }^{73}$ As the social structure is different in different periods of social history, ${ }^{74}$ it is necessary to develop a system of social identification to distinguish the informants by their social class and educational background during the ER. In this article, the proposal of six social classes at any given time in American history ${ }^{75}$ will be used as a starting point. The classification includes an upper-upper class that does not work but hires and supervises those who supervise the labor of others while possessing enough wealth so as to live off in material splendor. There is a lowerupper class which is equal in wealth to the Upper-upper class but has less social acceptability and an upper-middle class which is characterized by living extremely well while the lower-middle class is composed of small shopkeepers, clerks, white collar workers, and small farmers of modest properties who have minimal social influence. The upper-lower class is composed of semiskilled workers and marginal farmers and the lower-lower class consists of tenant farmers, agricultural laborers, and pre-Civil War blacks (in the Early American Republic).

The system of social classification for the study took that classification as a reference and grouped the informants to contemplate the educational background (literacy and access to formal education) and the social changes during the ER. ${ }^{76}$ In addition, the classification observed the characterization of speakers by degrees of literacy and social contact in the Handbook of the Linguistic Geography of New England ${ }^{77}$ which is:

Type I - little formal education, little reading, restricted social contact.

Type II - better formal education (usually high-school) and/or wider reading and social contacts.

73. S. Wilentz, "On Class and Politics in Jacksonian America," 1982; E. Pessen, "Social Structure and Politics in American History," 1982; C. Clark, "Comment on the Symposium on Class in the Early Republic,"2005, 558.

74. J. T. Main, The Social Structure of Revolutionary America, 1965; E. Pessen, "Social Structure and Politics in American History," 1982; M. Zakim, M. "The Business Clerk as Social Revolutionary; or, a Labor History of the Non-Producing Classes," 2006; D. Gilbert, The American Class Structure in an Age of Growing Inequality (Thousand Oaks, CA: Pine Forge Press, 2011).

75. E. Pessen, “Social Structure and Politics in American History," 1982, 1297-1300.

76. J. T. Lemon and G. B. Nash, "The Distribution of Wealth in Eighteenth-Century America," 1968; J. M. Faragher, "History from the Inside-Out: Writing the History of Women in Rural America," 1981; E. Pessen, "Social Structure and Politics in American History," 1982; G. S. Wood, "The Significance of the Early Republic," 1988; M. Zakim, M. "The Business Clerk as Social Revolutionary; or, a Labor History of the Non-Producing Classes," 2006.

77. H. Kurath, et al., Handbook of the Linguistic Geography of New England (Providence: Brown University for the American Council of Learned Societies, 1939). 
Type II - superior education (usually college), cultured background, wide readings, and/or extensive social contacts.

The resulting system for social identification contemplates the existence of a lower-lower class with no formal education and minimal reading that is composed by slaves, white servants, landless laborers and tenant farmers. An upper-lower class composed of marginal farmers and artisans (weavers, carpenters, coopers, tailors) who have very little formal education and minimal reading. A lower-middle class composed of clerks, small merchants, small factories owners, small farmers and prosperous artisans who had better but still limited formal education and wider reading. An upper-middle class composed of manufacturing leaders and large farm owners with better education and wider reading, followed by a lower-upper class composed of people from the industrial and commercial sector like ship owners, officers, and politicians who had formal education and wider reading. Finally, an upper-upper class composed of bankers, wealthy farmers or planters, urban merchants and high-level politicians who had a superior education, cultured background and wider reading. They modelled themselves on the English aristocracy and embodied the ideal of refinement and gentility.

All in all, the organization of the society and, mostly, the importance of the middle class during the ER should be evaluated as a relevant factor influencing the process of linguistic change. At the same time, it may be considered that high prestige and low prestige varieties could be connected to how the different occupations were evaluated by the speech community.

Finally, the examination should also investigate secondary sources consisting of documents that discuss or that indirectly provide information of the linguistic situation at the time: elocution manuals, dictionaries, grammars, literary works and commentaries from travelers. Elocution manuals, dictionaries and grammars provide scholarly evaluation of speech that complements other evidence while commentaries from travelers would supply biased opinions. Moreover, since language changes in different ways in different places, ${ }^{78}$ it is important to access the geographic distribution of variation. In that case, the comments from travelers visiting and comparing the different regions and the comparison of different varieties in instructional material would represent a significant contribution.

\section{Conclusion}

While the social structure of the U.S. has been invariable in terms of number of classes $^{79}$ the particulars of each class have changed in the different historical

78. P. Trudgill, Sociolinguistics: An Introduction to Language and Society, 2000, 81.

79. E. Pessen, "Social Structure and Politics in American History," 1982. 
periods. Therefore, when analyzing linguistic data from the ER the socioeconomic and cultural characteristics of the time should be considered. At the same time, the rivalry between the North and the South and the territorial expansion should be contemplated because they might have had great influence on the diffusion of the language changes. Moreover, due to the need to collect data in texts written by semi illiterate informants, there will be an unbalance in terms of social rank representation. Likewise, it is probable that women will be underrepresented. Finally, the documents should be selected giving preference to texts that are less standardized and more similar to normal speech.

\section{Bibliography}

Algeo, J. The Cambridge History of the English Language. Volume VI: English in North America. UK: Cambridge University Press, 2001.

Altenbaugh, R. Historical Dictionary of American Education. Connecticut/London: Greenwood Publishing Group, 1999.

Bartram, W. Travels through North \& South Carolina, Georgia, East \& West Florida, the Cherokee Country, the Extensive Territories of the Muscogulges, or Creek Confederacy, and the Country of the Chactaws; Containing an Account of the Soil and Natural Productions of Those Regions, together with Observations on the Manners of the Indians. Embellished with Copper-Plates. Philadelphia: Printed by James \& Johnson, 1791.

Clark, C. "Comment on the Symposium on Class in the Early Republic." Journal of the Early Republic 25, no. 3 (2005): 557-564.

Dillard, J. L. Perspectives on American English. The Hague: Mouton, 1980.

Faragher, J. M. "History from the Inside-Out: Writing the History of Women in Rural America." American Quarterly 33, no. 5 (1981): 537-557.

Fisher, J. "British and American, Continuity and Divergence." In The Cambridge History of the English Language, edited by J. Algeo, 59-85. Cambridge: Cambridge University Press, 2001.

Ford, D. Journal of an Expedition Made in the Autumn of 1794. The New York Public Library, 1794.

Gallman, R. E. "Changes in the Level of Literacy in a New Community of Early America." The Journal of Economic History 48, no. 3 (1988): 567-582.

Gilbert, D. The American Class Structure in an Age of Growing Inequality. $8^{\text {th }}$ Edition. Thousand Oaks, CA: Pine Forge Press, 2011.

Grubb, F. W. "Growth of Literacy in Colonial America: Longitudinal Patterns, Economic Models, and the Direction of Future Research." Social Science History 14, no. 4 (1990): 451-482.

Harriott, J. Struggles through Life: Exemplified in the Various Travels and Adventures in Europe, Asia, Africa, \& America, of John Harriott. Dublin: John Exshaw, 1815.

Haugen, E. “Dialect, Language, Nation." American Anthropologist 68: (1966): 922-935.

Herndon, R. W. "Research Note: Literacy among New England's Transient Poor, 17501800." Journal of Social History 29, no. 4 (1996): 963-965.

Jones, H. The Present State of Virginia. NY: Reprinted for Joseph Sabin from 1724. London: J. Clarke, 1865. 
Kaestle, C. F. "The History of Literacy and the History of Readers." Review of Research in Education 12 (1985): 11-53.

Kurath, H. et al. Handbook of the Linguistic Geography of New England. Providence: Brown University for the American Council of Learned Societies, 1939.

Laing, M. "Multidimensionality: Time, Space and Stratigraphy in Historical Dialectology." In Methods and Data in English Historical Dialectology, edited by M. Dossena and R. Lass, 49-96. Germany: Peter Lang, 2004.

Lemon, J. T. and G. B. Nash. "The Distribution of Wealth in Eighteenth-Century America: A Century of Change in Chester County, Pennsylvania, 1693-1802" Journal of Social History 2, no. 1 (1968): 1-24.

Main, J. T. The Social Structure of Revolutionary America. Princeton: Princeton University Press, 1965.

Mersman, J. J. The Whiskey Merchant's Diary. Edited by L Fisher. Ohio: Ohio University Press, 2007.

Montgomery, M. "The History of American English." In Needed Research in American Dialects, edited by D. R. Preston, 1-23. Durham, N.C.: Duke University Press, 2004.

Montgomery, M. "The Crucial Century for English in the American South." In New Perspectives on Language Variety in the South: Historical and Contemporary Approaches, edited by M. D. Picone and C. E. Davis, 97-117. Tuscaloosa, Alabama: The University of Alabama Press, 2015.

Parker, A. A. Trip to the West and Texas. USA: Concord, 1835.

Pessen, E. "Social Structure and Politics in American History." The American Historical Review 87, no. 5 (1982): 1290-1325.

Purvis, J. “Using Primary Sources When Researching." Women's History from a Feminist Perspective, Women's History Review 1, no. 2 (1992): 273-306.

Read, A. W. "British Recognition of American Speech in the Eighteenth Century." In Perspectives on American English, edited by J. L. Dillard, 15-35. The Hague: Mouton, 1980.

Schele De Vere, M. Americanisms: the English of the New World. New York: C. Scribner \& company, 1872.

Schneider, E. "Investigating Historical Variation and Change in Written Documents." In The Handbook of Language Variation and Change, edited by J. K. Chambers, P. Trudgill and N. Schilling-Estes, 67-96. Oxford/Malden, MA: Blackwell, 2002.

St. John de Crèvecoeur, J. H. Letters from an American Farmer. London: For the Author, 1782.

Trudgill, P. Sociolinguistics: An Introduction to Language and Society. London: Penguin, 2000.

Trudgill, P. and R. J. Watts (Eds.) Alternative Histories of English. London/NY: Routledge, 2002.

Twining, T. Travels in America 100 Years Ago: Being Notes and Reminiscences. New York: Harper and Brothers, Publishers, 1894.

Wilentz, S. "On Class and Politics in Jacksonian America." Reviews in American History 10, no. 4 (1982): 45-63.

Wood, G. S. "The Significance of the Early Republic." Journal of the Early Republic 8, no. 1 (1988): 1-20.

Zakim, M. "The Business Clerk as Social Revolutionary; or, a Labor History of the NonProducing Classes." Journal of the Early Republic 26, no. 4 (2006): 563-603. 